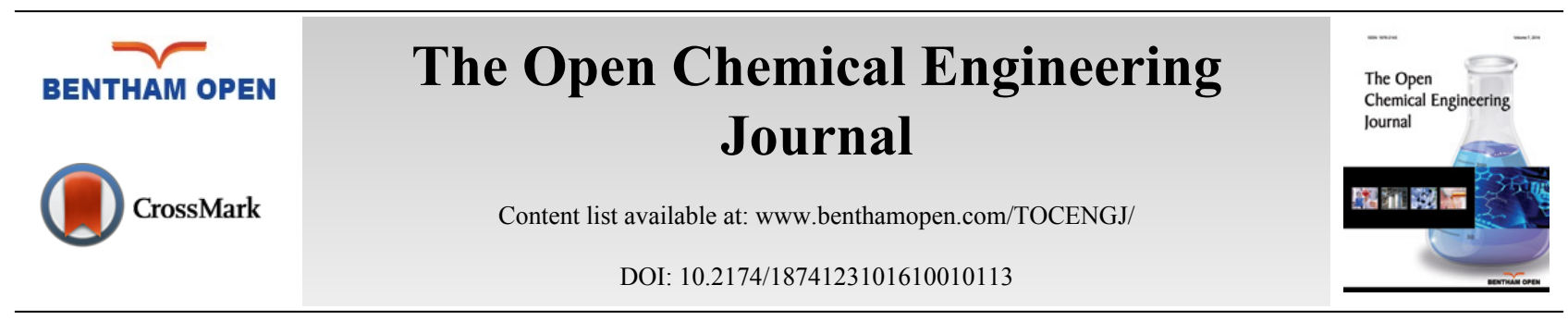

RETRACTION

\title{
Retraction Notice: Study of Water-rock Interaction with Hydrochemical and Isotopic Datum in Laizhou Bay
}

Liu Feng", Ma Fengshan, Guo Jie and Ding Kuo

Key Laboratory of Institute Shale Gas and Geoengineering, Institute of Geology and Geophysics, Chinese Academy of Sciences, 100029, Beijing

\section{RETRACTION}

The Publisher and Editor have retracted this article [1] in accordance with good ethical practices. After a thorough investigations we believe that the peer review process was compromised. The article was published on-line on 31-08-2015.

\section{REFERENCE}

[1] L. Feng, M. Fengshan, G. Jie, and D. Kuo, "Study of water-rock interaction with hydrochemical and isotopic datum in laizhou bay", Open. Chem. Eng. J., vol. 9, pp. 90-97, 2015.

(C) Feng et al.; Licensee Bentham Open.

This is an open access article licensed under the terms of the Creative Commons Attribution-Non-Commercial 4.0 International Public License (CC BY-NC 4.0) (https://creativecommons.org/licenses/by-nc/4.0/legalcode), which permits unrestricted, non-commercial use, distribution and reproduction in any medium, provided the work is properly cited.

\footnotetext{
* Address correspondence to this author at the Key Laboratory of Institute Shale Gas and Geoengineering, Institute of Geology and Geophysics, Chinese Academy of Sciences, Beijing 100029; E-mail: ??????????????
} 